\title{
Immunocytochemical Evidence for Peptidergic (GnRH) and Dopaminergic Innervation of the Gonadotropic Cells in the Pituitary of the African Catfish, Clarias gariepinus
}

\author{
J. Peute,${ }^{*}$ R. G. Schild,$*$ V. A. Schild,$\dagger$ R. M. Buijs, $\nmid$ L. A. C. van Asselt,${ }^{*}$ AND \\ P. G. W. J. VAN OORDT*
}

${ }^{*}$ Research Group for Comparative Endocrinology, Department of Experimental Zoology, University of Utrecht, Padualaan 8, 3584 CH Utrecht, the Netherlands, and †Netherlands Institute for Brain Research, Meibergdreef 33, 1105 AZ Amsterdam, the Netherlands

Accepted April 9, 1987

\begin{abstract}
The proximal pars distalis (PPD) of the pituitary of the African catfish, Clarias gariepinus, was studied with immunocytochemical methods at the ultrastructural level. Antiserum raised against synthetic mammalian luteinizing hormone-releasing hormone (LHRH) was applied on Lowicryl-embedded pituitaries and the antigenic sites were visualized with protein A-gold. In nerve fibers contacting the gonadotropic cells, granulated vesicles with a diameter of $90-120 \mathrm{~nm}$ were labeled after this procedure, whereas the glandular cells were not labeled. For the immunocytochemical demonstration of dopaminergic fibers, the preembedding method was performed on Vibratome sections, using highly specific antibodies against dopamine. Immunoreactivity was restricted to fibers containing granulated vesicles with a diameter of approximately $80 \mathrm{~nm}$ and terminating on gonadotropic cells. The present data support the results of earlier in vivo and in vitro studies on the catfish pituitary, indicating a dual neuroendocrine regulation of the gonadotropic cells. 1987 Academic Press, Inc.
\end{abstract}

An important factor in the regulation of the reproductive cycle of the African catfish, Clarias gariepinus, is the secretory activity of the gonadotropic cells (Peute $e t$ al., 1986). These cells, located in the proximal pars distalis (PPD) of the pituitary, were immunocytochemically identified at the light and the electron microscopic level (Peute et al., 1984).

Concerning the regulation of the secretion of gonadotropic hormone (GTH) in teleosts, there is increasing experimental evidence for a dual neurohormonal control (cf. Peter 1983; Van Oordt and Peute 1983); i.e., secretion is stimulated by a gonadotropinreleasing hormone (GnRH) and inhibited by dopamine (DA). In the African catfish a superactive analog of synthetic mammalian luteinizing hormone-releasing hormone (LHRHa) stimulated the release of GTH from cultured gonadotrops (De Leeuw et al., 1984). In vivo injection of LHRHa re- sulted in an increase in plasma GTH; this effect could be potentiated by simultaneously adding a DA receptor antagonist (Chang and Peter, 1984; De Leeuw et al., 1985; Goos et al., 1987).

Recently Goos et al. (1985) established the presence and localization of LHRH immunoreactivity in brain and pituitary of the African catfish at the light microscopic level. The authors observed immunoreactive perikarya in the preoptic nucleus (NPO), as well as immunoreactive fibers running toward the pituitary and terminating between the glandular cells in the PPD. Preliminary results of Corio et al. (1985) showed the presence of immunoreactive DA neurons in the nucleus ventromedialis, the nucleus posterioris periventricularis, and the lateral extensions of the nucleus lateralis tuberis of the African catfish; the authors did not observe DA-immunoreactive fibers in the PPD. Additional sup- 
port for control by more than one neurotransmitter (neurohormone) has been obtained by the ultrastructural observation that the gonadotropic cells of the African catfish are innervated by two morphologically different types of nerve fibers, i.e., type A fibers with secretory vesicles larger than approximately $100 \mathrm{~nm}$ and type $B$ fibers with secretory vesicles of approximately $80 \mathrm{~nm}$ (Peute et al., 1984). Such a direct innervation of pars distalis cells is frequently encountered in teleosts, which lack a functional hypothalamo-hypophyseal portal system (cf. Ball, 1981). In this respect, teleosts represent a good model for the study of neuroendocrine control of pituitary functions by characterizing the fibers directly innervating the glandular cells.

The aim of the present study is to elucidate the nature of the fibers contacting the catfish gonadotrops. As a consequence of the physiological studies mentioned above it was decided to concentrate on $\mathrm{GnRH}$ and DA. For the immunocytochemical demonstration of $\mathrm{GnRH}$, an antibody that was raised against synthetic mammalian LHRH and directed against both terminal amino acids was used (Blähser, 1984). Since it was found that the GnRH of other teleosts, including the chum salmon, Oncorhynchus nerka (Sherwood et al., 1983), and the cod, Gadus morhua morhua (Wu et al., 1986), differs from mammalian LHRH only in the seventh and eighth amino acid positions, it was assumed that catfish GnRH could be recognized by this anti-LHRH also. Preliminary postembedding immunocytochemical staining of Epon sections with antiLHRH did not result in satisfactory labeling of nerve fibers. Thus it was decided to embed the pituitaries in Lowicryl $\mathrm{K}_{4} \mathrm{M}$, a polar embedding medium in which the antigenecity is preserved to a large extent and the background labeling is low (Bendayan and Shore, 1982; Roth and Berger, 1982). In the present study an antibody raised against glutaraldehyde conjugated dopamine (Geffard et al., 1984) was used to study the ultrastructural localization of dopamine in the catfish hypophysis.

\section{MATERIALS AND METHODS}

Animals. Ten mature male and eighteen mature female African catfish, Clarias gariepinus, were used; they were 12 to 18 months of age and weighed $400-600 \mathrm{~g}$. The fish were raised in the Department of Experimental Zoology of the University of Utrecht and kept in a copper-free recirculating system under a simulated normal photoperiod for The Netherlands, at a temperature of $25 \pm 1^{\circ}$. They were fed with Trouvit trout food (Trouw, Putten, The Netherlands). Six females were injected intraperitoneally with the monoamine oxidase inhibitor Pargyline $(75 \mathrm{mg} / \mathrm{kg}$, dissolved in a physiological salt solution; Sigma) 12 and $1 \mathrm{hr}$ before sacrifice. Without prior anesthesia the fish were decapitated and the pituitaries dissected.

Immunocytochemical procedures. (I) For the demonstration of GnRH the pituitaries were cut in six to eight pieces and fixed for $90 \mathrm{~min}$ in a mixture of $4 \%$ formaldehyde and $1 \%$ glutaraldehyde $(1: 1)$ in $0.1 \mathrm{M}$ sodium cacodylate buffer, $\mathrm{pH} 7.2$, at $0^{\circ}$. Without postfixation in $\mathrm{OsO}_{4}$, the tissues were dehydrated in graded ethanol, while stepwise lowering the temperature from 0 to $-25^{\circ}$. The dehydrated tissue was kept for $1 \mathrm{hr}$ at $-25^{\circ}$ in subsequently (i) a 1:1 mixture of ethanol $100 \%$ and Lowicryl $\mathrm{K}_{4} \mathrm{M}$ (Bulzers Union $\mathrm{Ag}$, Liechtenstein), (ii) a 1:2 mixture of ethanol $100 \%$ and Lowicryl $\mathrm{K}_{4} \mathrm{M}$, and (iii) pure resin. After an infiltration overnight in pure resin at $-25^{\circ}$, the tissues were placed in gelatin capsules filled with freshly made resin. The blocks were polymerized for $24-26 \mathrm{hr}$ at $-25^{\circ}$, while placed under two $15-\mathrm{W}$ uv fluorescent tubes at a distance of $30 \mathrm{~cm}$. After polymerization the blocks were allowed to equilibrate at room temperature and after removal of the capsules they were stored in a desiccator with $\mathrm{CaCl}_{2}$. Thin sections were cut with glass knives and mounted on 300-mesh nickel grids. Without prior etching, the scctions were treated with the antiserum 80-2 against LHRH (prepared and characterized by Blähser, 1984), in a dilution of 1:500 in $0.06 M$ Tris $-\mathrm{NaCl}, \mathrm{pH}$ 7.6. This antiserum shows cross-reactivity with catfish GnRH (Goos et al., 1985). The primary antibodies were labeled with protein A-gold, according to Peute et al. (1984). Two types of protein A-gold complexes were applied (prepared according to Van Bergen en Henegouwen and Leunissen, 1986): (i) a complex with gold particles of $\pm 7 \mathrm{~nm}$, in a dilution of 1:300 in phosphate-buffered saline containing $0.2 \%$ gelatin and $0.5 \%$ bovine serum albumin (PBG); and (ii) a complex with gold particles of $\pm 10 \mathrm{~nm}$, used in a dilution of 1:25 in PBG. Controls included adsorptions of the anti-LHRH serum with 10,50 , or $100 \mathrm{n} M$ synthetic LHRH (Intervet, Box- 
meer, The Netherlands) and substitution of the primary antiserum by normal serum or Tris $-\mathrm{NaCl}$.

(II) For the demonstration of DA at its original sites, the pituitaries had to be fixed within 1 min after decapitation. To achieve that end, immediately after decapitation $2 \mathrm{ml}$ of the fixative was injected via a hollow needle through the base of the skull, at the site of the pituitary. Subsequently the skull was opened and the pituitary removed, followed by the immersion fixation (60 min) of the caudal half of the pituitary, containing the PPD. The fixative consisted of $5 \%$ glutaraldehyde $-0.05 \mathrm{M}$ cacodylate buffer- $1 \% \mathrm{Na}_{2} \mathrm{~S}_{2} \mathrm{O}_{5}, \mathrm{pH} 7.5$. After fixation $50-\mu \mathrm{m}$ sections were made on a Vibratome in $0.05 M$ Tris $-\mathrm{HCl}-1 \% \mathrm{Na}_{2} \mathrm{~S}_{2} \mathrm{O}_{5}, \mathrm{pH}$ 7.2. These sections were handled with a paintbrush and placed in vials. The following incubations were carried out: (1) DA antiserum diluted 1:4000 in Tris buffer containing $1 \% \mathrm{Na}_{2} \mathrm{~S}_{2} \mathrm{O}_{5}$ for $18 \mathrm{hr}$ at $4^{\circ} \mathrm{C}$; (2) washing in $0.9 \%$ $\mathrm{NaCl}-0.05 M$ Tris buffer, pH 7.6, $3 \times 10 \mathrm{~min}$; (3) goat anti-rabbit 1:100, $60 \mathrm{~min}$; (4) washing in $0.9 \%$ $\mathrm{NaCl}-0.05 M$ Tris buffer; (5) peroxidase-antiperoxidase 1:1000, $40 \mathrm{~min}$; (6) washing in $0.9 \% \mathrm{NaCl}-0.05 \mathrm{M}$

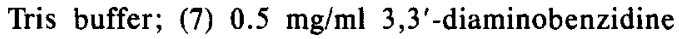
(Sigma) and $0.002 \% \mathrm{H}_{2} \mathrm{O}_{2}$ in Tris-saline, 5-10 min. For electron microscopy the procedure was followed by (8) washing in Tris-saline, $10 \mathrm{~min}$; (9) $1 \% \mathrm{OsO}_{4}$ in $0.1 M$ cacodylate buffer, $60 \mathrm{~min}$; (10) dehydration in a graded ethanol series; and (11) flat embedding in Epon 812. Ultrathin sections of the region containing the PPD were contrasted with a saturated uranylacetate solution in $70 \%$ methanol and examined in a Philips EM 400 or a Zeiss EM 10 electron microscope. The DA antibody was obtained by immunizing rabbits with DA conjugated with glutaraldehyde to a protein carrier according to Geffard et al. (1984). Specificity controls for the anti-DA serum included the solid-phase adsorption with DA- or NA-covered Sepharose beads (Buijs et al., 1984).

\section{RESULTS}

\section{LHRH Immunoreactivity}

In thin sections of Lowicryl-embedded pituitaries of the African catfish the PPD is readily recognized, due to the presence of three morphologically well-defined glandular cell types, i.e., the somatotrops, the thyrotrops, and the gonadotrops (Fig. 1). Compared to Epon-embedded material the quality of the Lowicryl sections is less, though sufficient to recognize different cell. types and nerve fibers, but not sufficient to distinguish synaptic specializations. Since no osmium tetroxide could be used prior to embedding, the plasma membranes are poorly visualized. From the morphologically distinguishable types of nerve fibers in the PPD (Peute et al., 1984), certain fibers with electron-dense granules larger than $100 \mathrm{~nm}$ were labeled after the application of anti-LHRH and protein A-gold, and others were not (Fig. 2). The fibers containing LHRH-immunopositive granules were often apposed to or in the proximity of the gonadotropic cells; true synapses could not be distinguished with the present method (Fig. 3). The background labeling was extremely low; only in gonadotropic cells were some gold particles occasionally observed. After the adsorption of the diluted primary antiserum with $100 \mathrm{nM}$ synthetic LHRH, the immunocytochemical reaction was completely abolished; the same holds true for the substitution of the primary antiserum by normal serum or Tris$\mathrm{NaCl}$.

\section{DA Immunoreactivity}

Generally the ultrastructural preservation of pituitary tissue after the preembedding procedure is better than after the postembedding Lowicryl method. This is largely the result of a postfixation step with osmium tetroxide prior to dehydration and embedding in Epon. A disadvantage of the preembedding procedure, however, is the less sharp localization of the antigenic sites with the peroxidase-antiperoxidase method in comparison with the protein Agold labeling (compare Figs. 2 and 3 with Figs. 5-7).

At the light microscopic level the immunocytochemical reaction for DA on Vibratome sections of the catfish pituitary showed numerous stained fibers at the border of the PPD with the neurointermediate lobe and relatively few stained fibers in the PPD proper. At the ultrastructural level the dopamine positive reaction in the PPD appeared to be restricted to type B fibers, containing dense-core vesicles approximately $80 \mathrm{~nm}$ in diameter. After staining for dopamine, reaction product 

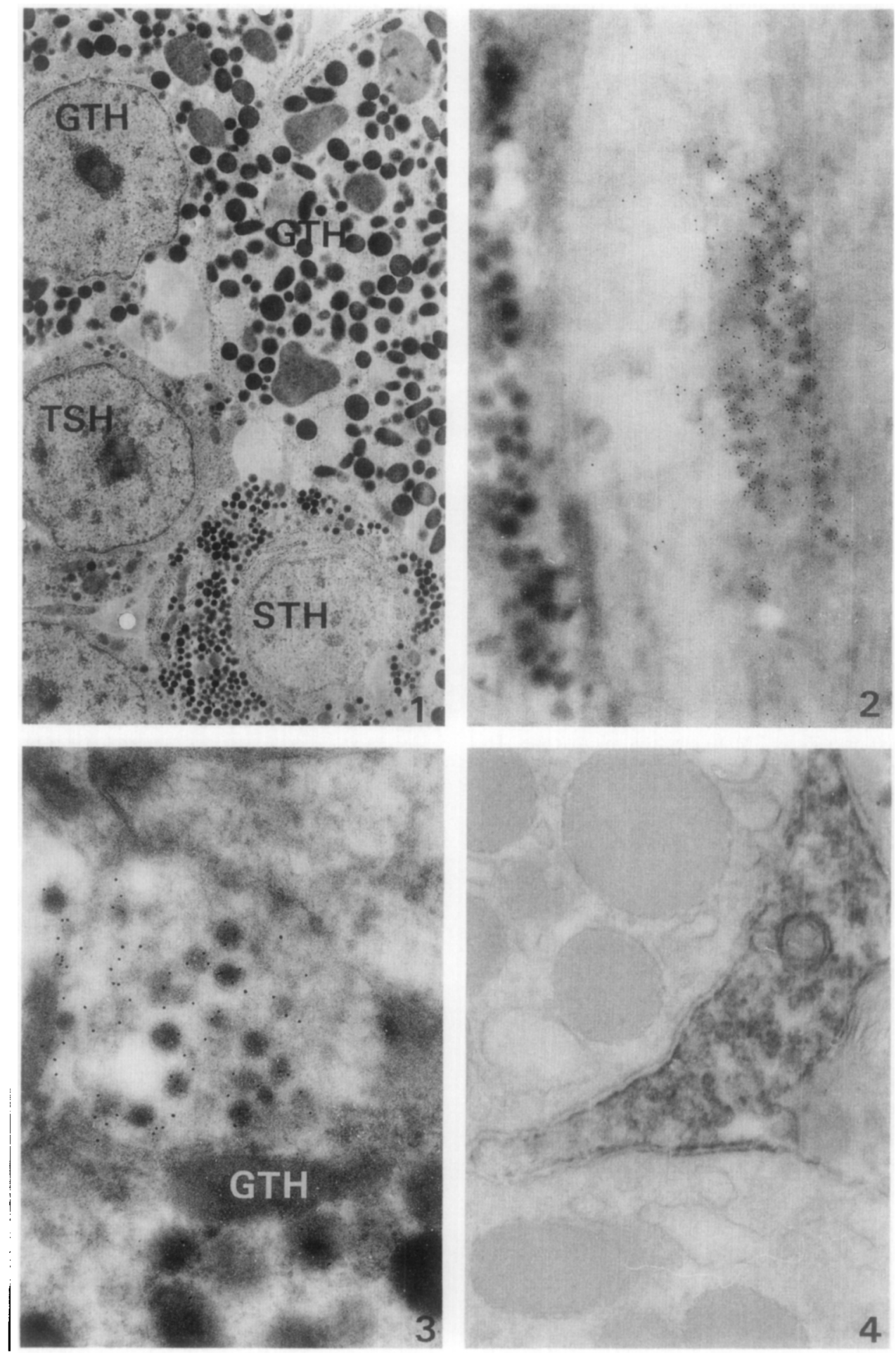
was clearly visible in these fibers which appeared to be in close contact with the glandular cells (Fig. 4). In the PPD of fish treated with Pargyline, DA-immunoreactive (DA-ir) nerve fibers were more numerous and the intensity of the reaction had increased considerably, allowing a further dilution of the primary antiserum from 1:4000 to 1:6000. DA-ir fiber endings contained many small vesicles $(40 \mathrm{~nm}$ in diameter) in addition to larger electron-dense vesicles ( $80 \mathrm{~nm}$ in diameter) (Fig. 5). On several occasions the small vesicles were clustered near the fiber membrane, the latter often showing an electron-dense thickening. Such terminals have been observed in contact with the gonadotrops (Figs. 5 and 6). Occasionally, a DA-ir fiber was observed in close association with a gonadotrop and located near a non-DA-ir synapse at the same cell; this latter synapse was identified as a type A fiber synapse, since it contained electron-dense vesicles larger than $100 \mathrm{~nm}$ in diameter (Fig. 7). Finally, apart from DA-ir type $B$ fibers and non-DA-ir type A fibers, non-DA-ir type $B$ synapses on gonadotropic cells were observed also (Fig. 8).

\section{DISCUSSION}

In the Lowicryl-embedded proximal pars distalis (PPD) of the African catfish, nerve fibers near GTH cells were selectively labeled with anti-LHRH. The size of the labeled granules in these fibers corresponds to the size of the granules in the type A fibers that were frequently found to be in synaptic contact with the GTH cells (Peute et al., 1984). Thus it is likely that the GTH cells are under direct, synapse-mediated, GnRH control, although in the nonosmicated and Lowicryl-embedded tissue synaptic membrane specializations could not be identified. A similar conclusion was reached by Batten (1986), who in nonosmicated pituitary glands of the molly, Poecilia latipinna, identified LHRH-ir profiles near GTH cells in the absence of synaptic specializations. On the other hand, increasing evidence exists that a nonsynaptic release of neuropeptides may also be involved in the regulation of glandular cells (Roubos and Van der Wal-Divendal, 1982). The present results suggest that, apart from a possible hormonal influence of $\mathrm{GnRH}$, the GTH cells can directly be influenced via synapse-like terminals of $\mathrm{GnRH}$ containing neurons. The significance of the regulation of GTH cell activity in teleosts by a LHRH-like peptide has been the subject of recent publications by Peter (1983) and De Leeuw et al. (1984, 1985, 1987). These authors also proved that DA inhibits GTH release. The present study provides immunocytochemical evidence for the existence of DA-ir terminals in synapse-like contact with GTH cells in the catfish pituitary gland. These contacts enable the neurotransmitter to interfere with the GTH release in a direct way. De Leeuw et al. $(1985,1987)$ obtained experimental evidence that in the catfish DA only inhibits the GnRH-stimulated GTH release. Therefore, most probably an intracellular mechanism determines the net effect of both GnRH and DA on the GTH release.

FIG. 1. Area of Lowicryl-embedded proximal pars distalis (PPD), with gonadotrops (GTH), a thyrotrop (TSH), and a somatotrop $($ STH) $(\times 9300)$.

FIG. 2. Two type A fibers in Lowicryl-embedded PPD; the secretory granules in one of the fibers are labeled with anti-LHRH/protein A-gold $(\times 16,500)$.

FIG. 3. A type A fiber in Lowicryl-embedded PPD, in close apposition to a GTH cell; the secretory granules are labeled with anti-LHRH/protein A-gold $(\times 32,100)$.

FIG. 4. Dopaminergic terminal contacting two GTH cells $(\times 48,000)$. 

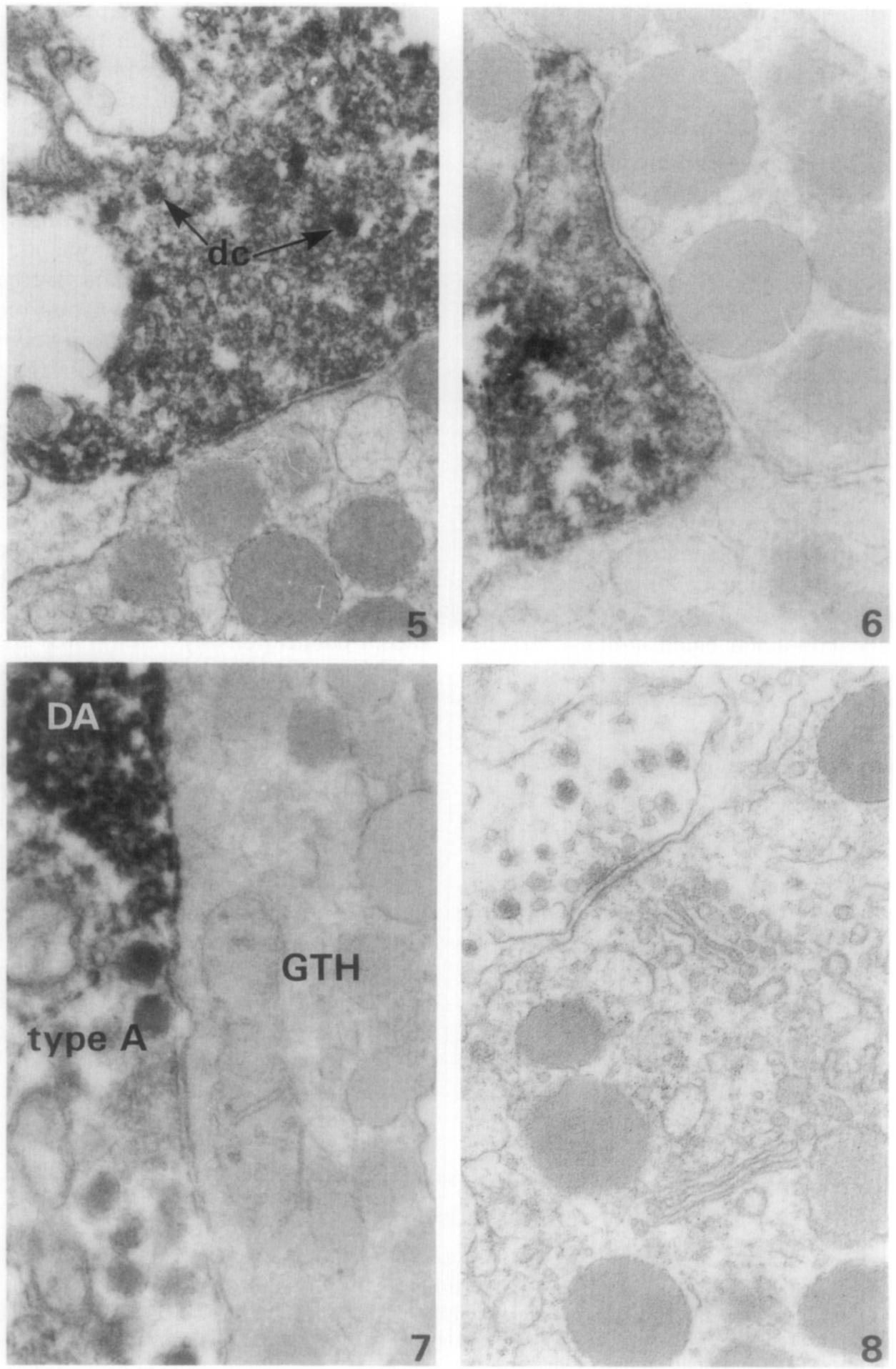
According to the terminology of Knowles and Vollrath (1966) the DA-ir fibers represent type B fibers, since the diameter of their electron-dense granules is less than $100 \mathrm{~nm}$. These results are in agreement with those of Kah et al. (1986), who, with a similar antibody, obtained DA immunoreactivity in type B fibers in the pituitary gland of the goldfish, Carassius auratus. The presence of immunoreactivity outside the vesicles often raises the question of whether DA might be present in an extravesicular pool (Kah et al., 1986). In our opinion the use of fixation procedures makes it highly unlikely that transmitter molecules can be fixed rapidly enough to prevent diffusion, especially when it concerns highly diffusable transmitters such as dopamine. Second, the preembedding staining technique using $\mathrm{DAB}$ as chromogen will often prevent conclusions on the actual site where DAB is formed and thus where the antigen is present.

Apart from LHRH-ir type A fibers and DA-ir type $B$ fibers, nonimmunoreactive fibers of type A and type B were also observed in the catfish PPD. This might indicate the existence of other neurosecretory fibers in this part of the pituitary gland. Indeed, Batten (1986) provided immunocytochemical evidence for the existence of vasotocin-, isotocin-, and somatostatin-immunoreactive type A fibers in the PPD of Poecilia latipinna, which differed from the LHRH-ir type A fibers. Similarly, not all type B fibers are necessarily aminergic, since it has been reported that such fibers may also concentrate tritiated $\gamma$-aminobu- tyric acid (GABA) or tritiated serotonin (cf. Kah et al., 1986). Preliminary results (V. Schild, unpublished observations) indicate that also in the catfish PPD some type B fibers appear to be immunoreactive for anti-GABA. For the neuroendocrine control of gonadotropin secretion, however, so far firm proof exists only for the involvement of GnRH and DA, and therefore a discussion as to the possible significance of GABA awaits further experimental data.

\section{ACKNOWLEDGMENTS}

The authors thank Mr. D. Smit for taking care of the photographic layout and Miss M. van Hattum for typing the manuscript. The LHRH antiserum was kindly provided by Dr. S. Blähser (Giessen, W. Germany).

\section{REFERENCES}

Ball, J. N. (1981). Hypothalamic control of the pars distalis in fishes, amphibians, and reptiles. Gen. Comp. Endocrinol. 44, 135-170.

Batten, T. F. C. (1986). Ultrastructural characterization of neurosecretory fibers immunoreactive for vasotocin, isotocin, somatostatin, LHRH and CRF in the pituitary of a teleost fish, Poecilia latipinna. Cell. Tissue Res. 244, 661-672.

Bendayan, M., and Shore, C. G. (1982). Immunocytochemical localization of mitochondrial proteins in the rat hepatocyte. J. Histochem. Cytochem. 30, 139-147.

Blähser, S. (1984). Peptidergic pathways in the avian brain. J. Exp. Zool. 232, 397-403.

Buijs, R. M., Geffard, M., Pool, C. W., and Hoorneman, E. M. D. (1984). The dopaminergic innervation of the supraoptic and paraventricular nucleus: A light and electron microscopical study. Brain Res. 323, 65-72.

Chang, J. P., and Peter, R. E. (1984). Effects of pimozide and Des Gly ${ }^{10}$ [D-Ala ${ }^{6}$ ]luteinizing hormonereleasing hormone ethylamide on serum gonado-

FIGS. 5 AND 6. Dopaminergic terminals forming synaptic contact with GTH cells; note the abundance of synaptic vesicles and a few dense-core vesicles $(\mathrm{dc})(\times 48,000)$.

FIG. 7. An immunoreactive dopaminergic terminal (DA) next to an unlabeled type A fiber synaptically contacting a GTH cell $(\times 48,000)$.

FIG. 8. Unlabeled type B fiber forming a synapse with a GTH cell. The $50-\mu$ thick Vibratome section from which the ultrathin section was prepared was treated with anti-dopamine, followed by the PAP procedure $(\times 48,000)$. 
tropin concentrations, germinal vesicle migration, and ovulation in female goldfish, Carassius auratus. Gen. Comp. Endocrinol. 52, 30-37.

Corio, M., Peute, J., Steinbusch, H. W. M., and Doerr-Schott, J. (1985). Immunoreactive dopaminergic neurons in the hypothalamus of a fish, Clarias lazera, and an amphibian, Xenopus laevis. Neurosci. Lett. Suppl. 22, 110.

De Leeuw, R., Goos, H. J. Th., Peute, J., Van Pelt, A. M. M., Burzawa-Gérard, E., and Van Oordt, P. G. W. J. (1984). Isolation of gonadotrops from the pituitary of the African catfish, Clarias lazera. Cell Tissue Res. 236, 669-675.

De Leeuw, R., Resink, J. W., Rooyakkers, E. J. M., and Goos, H. J. Th. (1985). Pimozide modulates the luteinizing hormone-releasing hormone effect on gonadotropin release in the African catfish, Clarias lazera. Gen. Comp. Endocrinol. 58, $120-127$.

De Leeuw, R., Goos, H. J. Th., and Van Oordt, P. G. W. J. (1987). The regulation of gonadotropin release by neurohormones and gonadal steroids in the African catfish, Clarias gariepinus. Aquaculture 63, 43-58.

Geffard, M., Buijs, R. M., Seguela, Ph., Pool, C. W., and Le Moal, M. (1984). First demonstration of highly specific and sensitive antibodies against dopamine. Brain Res. 294, 161- 165.

Goos, H. J. Th., de Leeuw, R., de Zoeten-Kamp, C., Peute, J., and Blähser, S. (1985). Gonadotropinreleasing hormone-immunoreactive neuronal structures in the brain and pituitary of the African catfish, Clarias gariepinus (Burcheli). Cell Tissue Res. 241, 593-596.

Goos, H. J. Th., Joy, K. P., de Leeuw, R., van Oordt, P. G. W. J., van Delft, A. M. L., and Gielen, J. Th. (1987). The effect of luteinizing hormone releasing hormone analogue (LHRHa) in combination with different drugs with anti-dopamine and anti-serotonine properties on gonadotropin release and ovulation in the African catfish, Clarias gariepinus. Aquaculture 63, 143-156.

Kah, O., Dubourg, P., Onteniente, B., Geffard, M., and Calas, A. (1986). The dopaminergic innervation of the goldfish pituitary. An immunocytochemical study at the electron-microscope level using antibodies against dopamine. Cell Tissue Res. 244, 577-582.

Knowles, F., and Vollrath, L. (1966). Neurosecretory innervation of the pituitary of the eels Anguilla and Conger. $I$. The structure and ultrastructure of the neurointermediate lobe under normal and experimental conditions. Phil. Trans. R. Soc. London, B 250, 311-327.

Peter, R. E. (1983). The brain and neurohormones in teleost reproduction. In "Fish Physiology" (W. S. Hoar, D. J. Randall, and E. M. Donaldson, Eds.), Vol. IX, pp. 97-135. Academic Press, New York/London.

Peute, J., de Leeuw, R., Goos, H. J. Th., and van Oordt, P. G. W. J. (1984). Ultrastructure and immunolabeling of gonadotrops and thyrotrops in the pituitary of the African catfish, Clarias lazera. Cell Tissue Res. 238, 95-103.

Peute, J., Zandbergen, M. A., Goos, H. J. Th., de Leeuw, R., Pinkas, R., Viveen, W. J. A. R., and van Oordt, P. G. W. J. (1986). Pituitary gonadotropin contents and ultrastructure of the gonadotrops in the African catfish, Clarias gariepinus, during the annual cycle in a natural habitat. Canad. J. Zool. 64, 1718-1727.

Roth, J., and Berger, E. G. (1982). Immunocytochemical localization of galactosyltransferase in Hela cells: Codistribution with thiamine pyrophosphatase in trans Golgi cisternae. J. Cell Biol. 93, 223-229.

Roubos, E. W., and Van der Wal-Divendal, R. M. (1982). Sensory input to growth stimulating neuroendocrine cells of Lymnaea stagnalis 1 . Cell Tissue Res. 227, 371-386.

Sherwood, N., Eiden, L., Brownstein, M., Spiess, J., Rivier, J., and Vale, W. (1983). Characterization of a teleost gonadotropin-releasing hormone. Proc. Natl. Acad. Sci. USA 80, 2794-2798.

Van Bergen en Henegouwen, P. M. P., and Leunissen, J. L. M. (1986). Controlled growth of colloidal gold particles and implications for labelling efficiency. Histochemistry 85, 81-87.

Van Oordt, P. G. W. J., and Peute, J. (1983). The cellular origin of the pituitary gonadotropins in teleosts. In "Fish Physiology" (W. S. Hoar, D. J. Randall, and E. M. Donaldson, Eds.), Vol. IX, pp. 137-186. Academic Press, New York/ London.

Wu, P., Ackland, J. F., Ling, N., and Jackson, I. M. D. (1986). Purification and characterization of luteinizing hormone-releasing hormone from codfish brain. Regul. Pept. 15, 311-321. 